\title{
Article
}

\section{Effect of feed restriction on fatty acid profile, body composition and selected blood parameters of intensive reared pike (Esox lucius)}

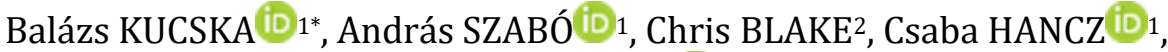 Dániel VARGA (iD) 1}

\author{
${ }^{1}$ Hungarian University of Agriculture and Life Sciences (MATE), Kaposvár Campus, Kaposvár \\ 2University of Waikato, Knighton Road, Hillcrest, Hamilton, New Zealand
}

\begin{abstract}
This study investigated the effects of a six-week starvation period on the fatty acid profile, body composition and blood parameters of intensively reared pike (Esox lucius). 150 pike were stocked in an experimental recirculating aquaculture system (RAS) and feed was completely withdrawn. Body composition, fatty acid composition and blood parameters (serum protein, albumin, triacylglycerol, cholesterol concentration and Lactate dehidrigenase and alkaline phosphatase activity) were measured and somatic indices were calculated. A significant decline in bodyweight, crude fat content and somatic indices was accompanied by a significant decrease of blood triacylglycerol content. The relative proportion of saturated fatty acids in the fillet decreased, while polyunsaturated fatty acids increased. There was also a significant increase in the average chain length and unsaturation index of fatty acids found in the fillet flesh.
\end{abstract}

Keywords: starvation, Esox lucius, fatty acids, PUFA, fillet

\section{INTRODUCTION}

Many fish species are affected by prolonged periods of starvation, related predominantly to seasonal changes in food availability and to spawning migrations (Friedrich and Stepanowska, 2001). However starvation is a major threat that fish often face in their natural aquatic ecosystem. Some fish can even survive for several months without consuming food, but once starvation reaches a certain point, it is a factor to influence fish growth, activity, and even survival (Feng et al. 2011).

In recent years it has become increasingly common to produce northern pike (Esox lucius) stocking material in recirculating aquaculture systems (RAS) because of the decrease of natural population (due to overfishing and decline of spawning grounds). The rearing and feeding conditions in these systems are controlled which ensures optimal fish growth and high survival rates (Szczepkowski et al. 2012). Due to advancements in rearing technologies, it is

\footnotetext{
*CORRESPONDING AUTHOR

Magyar Agrár- és Élettudományi Egyetem (MATE), Kaposvári Campus

$\triangle 7400$ Kaposvár, Guba Sándor u. 40., 唺 82/505-800

E-mail: kucska.balazs@uni-mate.hu
} 
now possible to conduct intensive rearing of juvenile pike in RAS using commercial, formulated feed (Wolnicki and Górny 1997; Kucska et al. 2005; Szczepkowski 2009).

After stocking pike from RAS into natural aquatic habitat fish have to adapt to the new environment. It may take some time to catch the first prey fish, which may result in starvation for a period of shorter or longer duration. Feeding of formulated diet can result in higher accumulation of perivisceral fat and higher lipid content of the fillet in comparisons with feeding prey fish (Kucska et al. 2006) which may influence the fuel metabolism during starvation.

There are only few studies on pike's metabolism (Kluytmans and Zandee 1973; Salam and Davies 1994; Khodadoust 2015). According to the results of Ince and Thorpe (1976) and Diana (1982) pike originated from natural habitats are well adapted for periods of prolonged starvation and that hepatic and extra-hepatic lipid and glycogen stores serve for metabolic fuels during food shortage, while body protein is conserved. However there is no information available about physiology of starvation of pike raised on artificial diet.

For the better understanding of pike's metabolism during fasting, the aim of the current study was to investigate the metabolic effects (changes in fatty acid composition, blood chemical parameters and proximate body composition) of starvation on northern pike fed antecedent with a commercial diet.

\section{MATERIAL AND METHODS}

The study was carried out on pike grown in an experimental RAS system and fed exclusively with a commercial fish feed (Table 1) ad libitum prior to the trial. At the beginning of the experiment 150 individuals were randomly assigned into tanks (w0: $128.2 \pm 21.7 \mathrm{~g}$ ). The fish were stocked into five $300 \mathrm{~L}$ tanks, in a recirculation system (30 fish each). Feeding was totally withdrawn for 6 weeks. The experiment was designed according to a previous study on starved common carp, in which the initial condition was used as a control (Varga et al. 2014, 2016).

The dissolved oxygen was kept close to $100 \%$ saturation. The water temperature was $18.3 \pm 1.5^{\circ} \mathrm{C}$, the flow rates were set to achieve a water exchange of $150 \%$ tank- $^{-1} \mathrm{~h}-1$.

Sample collection was carried out initially and every two weeks during the duration of the experiment. At every sampling time 15 randomly selected individuals were over-anaesthetized with clove oil (Ntotal $=4$ (timepoint) $\times 15$ (fish) $=60$ ). Blood samples were then taken from the tail vein (vena caudalis). After withdrawal into Eppendorf tubes the blood was immediately placed on ice, left to clot, centrifuged (1500 g / $10 \mathrm{~min}$ ) and then the serum was stored 
frozen $\left(-70^{\circ} \mathrm{C}\right)$ until analysis. Clinical chemical analysis (serum protein, albumin, triacylglycerol, cholesterol concentration, and LDH and ALP activity) was performed on automated equipment (Hitachi 917) in a single analytical run.

\section{Table 1}

Proximate composition of the diet fed ad libitum prior to the trial (declared by Aller Aqua)

\begin{tabular}{lc}
\hline Name & Aller Sturgeon rep. ex \\
\hline Crude protein,\% & 52 \\
Crude fat, \% & 12 \\
Nitrogen free extract, \% & 17.9 \\
Gross energy, Kj/kg & 20.3 \\
\hline
\end{tabular}

Weight and standard length were measured. Following these 10 fish were dissected than viscera and liver were weighted. Somatic indices, such as viscerosomatic index (VSI) and hepatosomatic index (HSI), and also condition factor (CF) were calculated: VSI = V / W x 100; HSI = H / W x 100; CF = W x L-3 x 100 , where V - weight of viscera; $\mathrm{H}$ - weight of liver; $\mathrm{W}$ - bodyweight; $\mathrm{L}$ standard length.

At the beginning and the end of the trial, another 5 individuals were analysed for total body composition after homogenisation. Dry matter content was determined after drying the samples in a vacuum oven at $50{ }^{\circ} \mathrm{C}$ and a vacuum of $13.3 \mathrm{kPa}$, using anhydrous calcium chloride as the drying agent. After $16 \mathrm{~h}$, the vacuum was changed to $0.2 \mathrm{kPa}$ and the samples were weighed every $4 \mathrm{~h}$ until they reached constant weight. Nitrogen content was determined from the fresh samples by Kjeldahl analysis according to ISO 5983 (ISO 1997). The crude fat content was determined by extraction of freeze-dried samples with petroleum-ether and drying the extract at $103^{\circ} \mathrm{C}$ to a constant weight according to ISO 6492 (ISO 1985). Crude ash was analysed by burning oven-dried samples in a muffle furnace at $550^{\circ} \mathrm{C}$ according to ISO 5984 (ISO 1978).

At the beginning and at the end of the trial 5-5 individuals' total body was analysed for fatty acid composition after homogenisation. Samples were extracted with the method of Folch et al. (1957). All solvents used were ultrapure-grade by Sigma-Aldrich (Schnelldorf, Germany), and $100 \mathrm{mg} \mathrm{L-1}$ butylated hydroxytoluene was added to the extraction mixture (chloroform/methanol $2 / 1 \mathrm{v} / \mathrm{v}$ ) as an antioxidant. Fatty acids were transmethylated by the base-catalysed sodium-methoxide method of Christie (1982).

Gas liquid chromatography was performed on a Shimadzu 2100 apparatus, equipped with a SP-2380 type capillary column (30 m x $0.25 \mathrm{~mm}$ ID, $0.20 \mu \mathrm{m}$ film, 24110-U, Supelco, USA) and flame ionisation detector (FID 2×10-11). 
Characteristic operating conditions were: injector temperature: $270{ }^{\circ} \mathrm{C}$, detector temperature: $300{ }^{\circ} \mathrm{C}$, helium flow: $28 \mathrm{~cm} / \mathrm{sec}$. The oven temperature was graded: from 80 to $205^{\circ} \mathrm{C}: 2.5^{\circ} \mathrm{C} / \mathrm{min}, 5 \mathrm{~min}$ at $205^{\circ} \mathrm{C}$, from 205 to $250{ }^{\circ} \mathrm{C} 10$ ${ }^{\circ} \mathrm{C} / \mathrm{min}$ and $5 \mathrm{~min}$ at $250^{\circ} \mathrm{C}$. To identify individual FA, an authentic FA standard (Supelco 37 component FAME Mix, Cat. No., Sigma-Aldrich, Schnellendorf, Germany) was used. Fatty acid results were expressed as weight $\%$ of total fatty acid methylesthers. Unsaturation index (UI) was defined as the number of double bonds in 100 fatty acyl chains.

The basic data were tested for normality (Shapiro-Wilk test). For the analysis of the effect of starvation on body composition and somatic indices oneway ANOVA was used (time as fixed factor), followed by Tukey post hoc test. For the analysis of the effect of starvation on FA composition, the independent samples t-test was used at the significance level of 0.05 . SPSS 20 for Windows (2009) was used for the statistical analyses.

\section{RESULTS AND DISCUSSION}

No mortality was observed during the trial. The changes in the body composition are given in Table 2. The six-week long period of food deprivation caused a strong increase in body water content and a reduction of the body lipids, however there was no significant difference in body protein content $(\mathrm{p}<0.05)$.

Table 2

Proximate body composition of the experimental fish

\begin{tabular}{llll}
\hline Traits & Initial & Final & P value \\
& Mean $\pm \mathrm{sd}$ & Mean $\pm \mathrm{sd}$ & \\
\hline Water content (\%) & $\mathbf{7 2 . 0 2} \pm \mathbf{0 . 8 6}$ & $\mathbf{7 3 . 8 2} \pm \mathbf{0 . 5 1}$ & $\mathrm{p}<0.01$ \\
Crude protein (\%) & $18.8 \pm 0.57$ & $18.4 \pm 0.41$ & NS \\
Crude fat (\%) & $\mathbf{5 . 1 4} \pm \mathbf{0 . 6}$ & $\mathbf{4 . 1 8} \pm \mathbf{0 . 6 5}$ & 0.042 \\
Crude ash (\%) & $3.48 \pm 0,19$ & $3.58 \pm 0.47$ & NS \\
\hline
\end{tabular}

NS: $p>0.05$

The somatic indexes (HSI, VSI and CF) decreased after 6 weeks (Figure 1).

The basic serum clinical chemical results are summarized in Table 3 . The six-week long starvation led to a significant decrease of triacylglycerol concentration $(\mathrm{p}<0.05)$. Serum total protein, albumin, cholesterol, ALP and LDH concentration did not show any significant change as a result of starvation. Some of the derived data for individual fatty acids of the fillet also showed significant differences after six weeks starvation. 


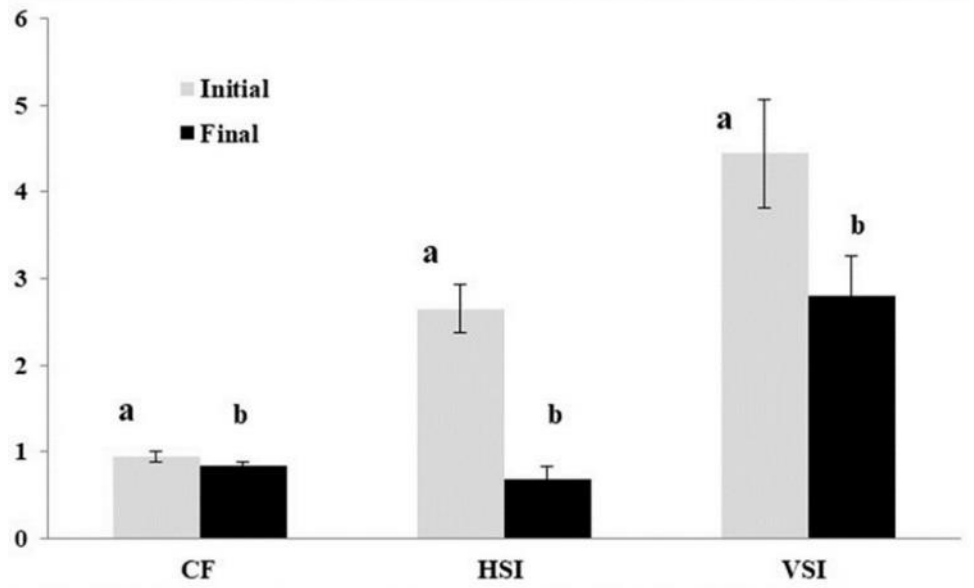

\section{Figure 1}

Changes in the somatic indices of pikes after 6 weeks starvation. The different letters indicate significant difference $(\mathrm{p}<0.05$; $\mathrm{t}$-test)

Table 3

The serum basic clinical chemical results of the pikes during the starvation

\begin{tabular}{llllll}
\hline Traits & \multicolumn{2}{l}{ Weeks in starvation } & \multicolumn{2}{l}{ P values } \\
& Initial & $\mathbf{2}$ & $\mathbf{4}$ & $\mathbf{6}$ & \\
& Mean \pm SD & Mean \pm SD & Mean \pm SD & Mean \pm SD & \\
\hline Total protein (g/l) & $27 \pm 2.74$ & $29.4 \pm 2.3$ & $25.2 \pm 1.79$ & $29 \pm 7.9$ & $\mathrm{NS}$ \\
Albumin g/l & $6.8 \pm 2.22$ & $8.8 \pm 2.17$ & $7.6 \pm 2.3$ & $7.2 \pm 2.39$ & $\mathrm{NS}$ \\
Cholesterol (mmol/l) & $5.66 \pm 1.21$ & $7.28 \pm 0.1$ & $5.44 \pm 0.8$ & $5.8 \pm 0.94$ & $\mathrm{NS}$ \\
Triacylglycerol (mmol/l) & $\mathbf{1 . 1 2} \pm \mathbf{0 . 3 5}$ & $\mathbf{0 . 5 4} \pm \mathbf{0 . 1}$ & $\mathbf{0 . 7 4} \pm \mathbf{0 . 3 5}$ & $\mathbf{0 . 4 6} \pm \mathbf{0 . 1}$ & $<\mathbf{0 . 0 1}$ \\
Alkaline phosphatase (IU/l) & $164.4 \pm 58.12$ & $199 \pm 55.0$ & $129.4 \pm 28.3$ & $103.2 \pm 39.91$ & $\mathrm{NS}$ \\
LDH (IU/l) & $780.6 \pm 159.87$ & $786 \pm 99.85$ & $759 \pm 177.21$ & $879.6 \pm 309.2$ & $\mathrm{NS}$ \\
\hline
\end{tabular}

Most outstanding changes in fatty acid (FA) composition are the increase of arachidonic acid (C20:4 n6), docosapentaenoic acid (DPA,C22:5 n3), docosahexaenoic acid (DHA, C22:6 n3) total n3 ratio, unsaturation index (UI) and average chain length(ACL) (see Table 4).

Several authors reported significant decrease of body lipids due to starvation. Vertebrates adapt to prolonged fasting by mobilizing fat stores and minimizing protein loss (Cherel et al. 1992). In this process triglyceride (TG) stores are being intensively hydrolysed (depleted), adding that a defined fatty acid preference order for the adipose TG has already been described. This fatty acid selective hydrolysis in the TGs may be attributed to numerous factors, such as fatty acid molecular properties and enzymatic characteristics of HSL (Raclot 
2003), leading ultimately to differences in the fatty acid supply of the organs. Fish store lipids in divergent body fat depots: intramuscularly, visceral, in the liver and under the skin. Fish species utilize stored lipids differently in case of food restriction. Atlantic salmon (Salmo salar) prefer the mobilization of intramuscular lipids (Einen et al., 2008), while white sturgeon (Acipenser transmontanus) mobilize the visceral fat instead (Hung, 1998). Therefore, decrease of lipid content affected by starvation can be better characterized by the total body lipid content (Falahatkar 2012).

In our study body fat content decreased significantly during six-week-long starvation. No decrease of body protein content was observed, the six-weeklong starvation did not induce protein catabolism. Protein is mobilized as a source of energy only after glycogen and crude lipid are used (Rossi et al 2015). Our results agree with the observations of Ince and Thorpe (1976), where with pike captured in nature they found no significant changes in muscle protein concentration, or in the response to amino-acid loading during the starvation period. Interestingly, Luo et al (2009) described the opposite: the muscle crude protein decreased in higher amount than muscle crude lipid; and muscle glycogen remained unchanged during starvation in channel catfish (Ictalurus punctatus). These differences can be explained by the different allocation of energy stores in tissues and organs between salmoniform and siluriform fish (Barreto-Curiel et al 2017)

The most obvious effects of starvation are the decrease of body weight, which can be seen in the condition factors. The decrease of VSI and HSI is attributable to the decrease of liver and visceral fat. During long term starvation fish complement the lacking energy by catabolism of several tissues. Main metabolizable tissues are visceral and hepatic fat store.

Blood triacylglycerol content was observed to significantly decrease. In case of starvation the role of glycerols gain importance as a glucose precursors (Friedrich and Stepanowska, 2001).

Importance of glucose as an energy source in fish appears limited compared to mammals (Enes et al. 2009). Glucose requirements of fasted fish for metabolic purposes is satisfied by glycogen degradation into glucose (glycogenolysis) or by de novo glucose synthesis through gluconeogenesis (Pilkis and Granner 1992).

Starving muscles shift the utilization of glucose by the $\beta$-oxidation of lipids. The observed decrease of blood TG concentration (coupled with the significant decrease of total body fat content) confirms that lipolysis of intramuscular lipids was the major energy source for locomotion during starvation of pike. It was supported by other authors (Hung et al. 1997; Shimeno et al. 1990) as well. 
There was a significant decrease in the crude fat content of the fish. At the same time there was a significant increase in the average chain length (ACL) and unsaturation index. This has important implications as one of the main health benefits of eating fish by human consumers come from long chain fatty acids. The increase of long chain PUFA with the simultaneous decrease of the ratio of SFA in starving organism is a well-known process. Selective retention of essential fatty acids is common for many living organisms. It can be explained that an organism has to maintain the unsaturation level and thus the integrity and fluidity of the biological membranes (Szabó et al. 2005).

Changes observed in the body FA composition are in part supported by data previously reported for other vertebrates. The decrease of the palmitic acid amount was supported by Chen and Cunnane (1992), reporting the same process in fasting rats. This underlines the great importance of palmitate as an oxidizable source in an energy deficient condition (Cunnane and Karmazyn 1988; Cunnane 1990). In contrast, the total proportion of polyenoic fatty acids was unaltered, most probably serving the maintenance of sarcolemma integrity and fluidity.

Most fish species (eg. common carp, Cyprinus carpio) are able to metabolise selected FA for their energy needs when they are in good condition (Zajic et al. 2013, Varga et al 2020). Fillet FA composition of atlantic salmon (Salmo salar) also showed similar change in cases of food deprivation; proportion of SFA decreased, while proportion of MUFA and PUFA significantly increased (Einen et al. 1998). Significant increase of PUFA in the liver of hybrid tilapia (Oreochromis mossambicus $x$ O. niloticus) was also described due to long-term starvation (De Silva et al., 1997). The relative changes of the several FA groups in starving fish can be different between species. FA composition of the phospholipid (PL) fraction changed significantly (MUFA increased) in sea bass (Dicentrarchus labrax) liver and fillet, whereas the triacylglycerol (TG) fraction remained unchanged (Delgado et al. 1994).

Varga et al (2020) described that mostly the MUFA of the liver were utilized in the $\beta$-oxidation in common carp (Cyprinus carpio) during 12 -weeks starvation. In contrast, with an opposite reaction, fillet PUFAs were highly conserved. Fillet PL FA composition has undergone slighter changes during the starvation period, which refers to the importance of membrane fluidity.

Summarizing our results, it seems that mostly the triglyceride fatty acidy with higher saturation level were utilized in the $\beta$-oxidation. In contrast, likewise an opposite reaction, PUFA were conserved in the fillet. 


\section{Table 4}

Fillet fatty acid composition of the experimental fish

\begin{tabular}{|c|c|c|c|}
\hline Fatty acid & $\begin{array}{l}\text { Initial } \\
\text { Mean } \pm \text { sd }\end{array}$ & $\begin{array}{l}\text { Final } \\
\text { Mean } \pm \text { sd }\end{array}$ & P value \\
\hline C12:0 & $0.03 \pm 0.0$ & $0.034 \pm 0.01$ & NS \\
\hline C13:0 & $0.02 \pm 0.0$ & $0.02 \pm 0.0$ & NS \\
\hline C14:0 & $5.046 \pm 0.14$ & $4.97 \pm 0.3$ & NS \\
\hline C14:1 & $0.048 \pm 0.01$ & $0.04 \pm 0.01$ & NS \\
\hline C15:0 & $0.432 \pm 0.01$ & $0.426 \pm 0,01$ & NS \\
\hline C16:0 & $19.49 \pm 0.67$ & $18.31 \pm 0.77$ & 0.03 \\
\hline C16:1 n7 & $4.77 \pm 0.12$ & $4.74 \pm 0.37$ & NS \\
\hline C17:0 & $0.32 \pm 0.01$ & $0.3 \pm 0.02$ & 0.04 \\
\hline C18:0 & $2.94 \pm 0.07$ & $3.09 \pm 0.05$ & NS \\
\hline C18:9 n9t & $0.15 \pm 0.04$ & $0.2 \pm 0.05$ & $<0.01$ \\
\hline C18:1 n9 & $27.18 \pm 1.04$ & $26.71 \pm 1.18$ & NS \\
\hline C18:1 n11 & $3.08 \pm 0.12$ & $2.8 \pm 0.06$ & NS \\
\hline C18:2 n6 & $14.08 \pm 0.54$ & $13.46 \pm 1.02$ & NS \\
\hline C18:3 n6 & $0.56 \pm 0.04$ & $0.59 \pm 0.12$ & NS \\
\hline C18:3 n3 & $2.66 \pm 0.19$ & $2.23 \pm 0.1$ & $<0.01$ \\
\hline C20:0 & $0.15 \pm 0.01$ & $0.16 \pm 0.02$ & NS \\
\hline C20:1 n9 & $3.08 \pm 0.12$ & $3.48 \pm 0.11$ & $<0.01$ \\
\hline C20:2 n6 & $0.26 \pm 0.03$ & $0.294 \pm 0.01$ & 0.045 \\
\hline C20:3 n6 & $0.26 \pm 0.02$ & $0.28 \pm 0.05$ & NS \\
\hline C20:3 n3 & $0.1 \pm 0.00$ & $0.1 \pm 0.01$ & NS \\
\hline C20:4 n6 & $0.39 \pm 0.03$ & $0.48 \pm 0.03$ & $<0.01$ \\
\hline C20:5 n3 & $4.1 \pm 0.2$ & $3.76 \pm 0.48$ & NS \\
\hline C22:1 n9 & $0.17 \pm 0.02$ & $0.23 \pm 0.01$ & $<0.01$ \\
\hline C22:5 n3 & $0.84 \pm 0.04$ & $1.11 \pm 0.1$ & $<0.01$ \\
\hline C22:6 n3 & $9.63 \pm 0.85$ & $11.95 \pm 0.65$ & $<0.01$ \\
\hline C23:0 & $0.07 \pm 0.01$ & $0.1 \pm 0.01$ & 0.013 \\
\hline C24:0 & $0.01 \pm 0.0$ & $0.014 \pm 0,01$ & NS \\
\hline C24:1 n9 & $0.15 \pm 0.02$ & $0.12 \pm 0.02$ & NS \\
\hline SFA & $28.42 \pm 0.85$ & $27.31 \pm 1.31$ & NS \\
\hline MUFA & $38.63 \pm 0.85$ & $38.31 \pm 1.31$ & NS \\
\hline PUFA & $32.87 \pm 0.94$ & $34.26 \pm 0.98$ & NS \\
\hline$\sum n 3$ & $17.32 \pm 0.93$ & $19.16 \pm 0.26$ & $<0.01$ \\
\hline$\sum n 6$ & $1.21 \pm 0.05$ & $1.35 \pm 0.17$ & NS \\
\hline n6/n3 & $0.07 \pm 0.00$ & $0.07 \pm 0.01$ & NS \\
\hline UI & $162.06 \pm 4.91$ & $173.41 \pm 2.57$ & $<0.01$ \\
\hline ACL & $17.88 \pm 0.04$ & $18.01 \pm 0.04$ & $<0.01$ \\
\hline
\end{tabular}

SFA: Saturated fatty acids; MUFA: Monounsaturated FA; PUFA: Polyunsaturated FA, UI: Unsaturation index; ACL: average chain length; NS: $p>0.05$ 


\section{CONCLUSIONS}

In conclusion, juvenile pike reared in RAS and which were previously fed with a dry diet, are able to tolerate a period of six weeks starvation without any adverse effect on health and metabolism. No proteolysis was indicated by the results of this study, providing evidence that pike primarily use lipids as an energy source during periods of starvation. The significant decrease in body weight and somatic indices were attributed to the breakdown of fat. Selective retention of PUFA within the body, and an accompanying decrease of SFA due to starvation can be the goal of further studies, because it has important implications for fillet quality and the nutritional value of pike produced in intensive RAS conditions.

Acknowledgment: This work was supported by the European Fisheries Fund Fisheries Operative Programme III. axis, European Fisheries Fund for Renewable Fisheries provided by the European Union and Hungarian Government and the projects GINOP-2.3.4-15-2016-00004 and GINOP-2.3.4-15-201600005.

\section{REFERENCES}

Barreto-Curiel, F., Focken, U., D'Abramo, L.R., Viana, M.T. (2017). Metabolism of Seriola lalandi during Starvation as Revealed by Fatty Acid Analysis and Compound-Specific Analysis of Stable Isotopes within Amino Acids. Plos One. 12(1) e0170124. D0I: 10.1371/journal.pone.0170124

Cherel, Y., Robi,n J.P., Heitz, A., Calgari, C., LeMaho, Y. (1992). Relationships between lipid availability and protein utilization during prolonged fasting. J Comp Phys 162, 305-313. DOI: $\underline{10.1007 / B F 00260757}$

Chen. Z.Y., Cunnane, S.C. (1992). Preferential retention of linoleic acid-enriched triacylglycerols in liver and serum during fasting. Am J Phys 263, 233-239. DOI: 10.1152/ajpregu.1992.263.2.R233

Christie, W.W. (1982). A simple procedure for rapid transmethylation of glycerolipids and choles-terylesters. J Lipid Res 23, 1072-1075. DOI: 10.1016/S0022-2275(20)38081-0

Cunnane, S.C. (1990). Differential utilization of long chain fatty acids during fasting-induced triacylglycerol depletion. III. Comparison of n-3 and n- 6 fatty acids in rat plasma and liver. Biochimica et Biophysica Acta, 1036, 64-70. DOI: 10.1016/0304-4165(90)90214-H

Cunnane, S.C., Karmazyn, M. (1988). Differential utilization of long chain fatty acids during triacylglycerol depletion. I. Rat heart after ischemic perfusion. Lipids 23, 62-64. DOI: $\underline{10.1007 / B F 02535306}$

Diana, J.S. (1982). An experimental analysis of the metabolic rate and food utilization of northern pike. Comp Biochem Phys, 71, 395-9. DOI: 10.1016/0300-9629(82)90424-8

Delgado, A., Estevez, A., Hortelando, P., Alejandre, M.J. (1994). Analyses of fatty acids from different lipids in liver and muscle of sea bass (Dicentrarchus labrax). Influence of temperature and fast-ing. C Biochem Phys, 108, 673-680. DOI: 10.1016/0300-9629(94)90354-9

De Silva, S.S., Gunasekera, R.M., Austin, C.M. (1997). Changes in the fatty acid profiles of hybrid red tilapia, Oreochromis mossambicus x O. niloticus, subjected to short term starvation, and a com-parison 
with changes in seawater raised fish. Aquaculture 153. 273-290. DOI: 10.1016/S0044$\underline{8486(97) 00035-5}$

Einen, O., Waagan, B., Thomassen, M.S. (1998). Starvation prior to slaughter in Atlantic salmon (Salmo salar) I. Effects on weight loss, body shape, slaughter- and fillet yield, proximate and fatty acid composition. Aquaculture 166. 85-104. DOI: 10.1016/S0044-8486(98)00279-8

Enes, P., Panserat, S., Kaushik, S., Oliva-Teles, A. (2009). Nutritional regulation of hepatic glucose metabolism in fish. Fish Physiol Biochem 35. 519-539. DOI: 10.1007/s10695-008-9259-5

Falahatkar, B. (2012). The metabolic effects of feeding and fasting in beluga Huso huso. Marine Env Res 82. 69-75. DOI: 10.1016/j.marenvres.2012.09.003

Feng, G., Shi, X., Huang, X., Zhuang, P. (2011). Oxidative Stress and Antioxidant Defenses after Long-term Fasting in Blood of Chinese Sturgeon (Acipenser sinensis). Pro Env Sci 8. 469-475. DOI: $\underline{10.1016 / j . p r o e n v .2011 .10 .074}$

Friedrich, M., Stepanowska, K. (2001). Effect of starvation on the nutritive value of carp (Cyprinus carpio L.) and selected biochemical components of its blood. Acta Icht Pisc 31. 29-36. DOI: $\underline{10.3750 / A I P 2001.31 .2 .03 ~}$

Folch, J., Lees, M., Sloane-Stanley, G.H. (1957). A simple method of the isolation and purification of total lipids from animal tissues. J Biol Chem 226. 497-509. DOI: 10.1016/S0021-9258(18)64849-5

Hung, S.S.O., Liu, W., Li, H., Storebakken, T., Cui, Y. (1997). Effect of starvation on some morphological and biochemical parameters in white sturgeon, Acipenser transmontanus. Aquaculture 151. 357 363. DOI: $10.1016 /$ S0044-8486(96)01506-2

ISO, 1978. Animal Feeding Stuffs. Determination of Crude Ash. ISO 5984. International Organization for Standardization

ISO, 1985. Animal Feeding Stuffs. Determination of Fat Content. ISO 6492. International Organization for Standardization

ISO, 1997. Animal Feeding Stuffs. Determination of Nitrogen Content and Calculation of Crude Pro-tein Content - Kjeldahl Method. ISO 5983. International Organization for Standardization

Ince, B.W., Thorpe, A., (1976). The effects of starvation and force-feeding on the metabolism of the northern pike, Esox lucius L. J Fish Biol 8. 79-88. DOI: 10.1111/j.1095-8649.1976.tb03909.X

Khodadoust, A.L. (2015). Study on some blood biochemical parameters of pike (Esox lucius Linnaeus, 1758) in Anzali wetland. Middle-East Journal of Scientific Research, 23. 155-159.

Kluytmans, J.H.F.M., Zandee, D.I. (1973). Lipid metabolism in the northern pike (Esox lucius) - II: The composition of the total lipids and of the fatty acids isolated from lipid classes and some tissues of the northern pike. Comp Biochem Phys 44. 459-466. DOI: 10.1016/0305-0491(73)90019-9

Kucska, B., Müller, T., Sári, J., Bódis, M., Bercsényi, M. (2005). Successful growth of pike (Esox lucius) on pellet at artificial condition. Aquaculture 246. 227-230. DOI: 10.1016/j.aquaculture.2005.01.013

Kucska, B., Pál, L., Müller, T., Bódis, M., Bartos, Á., Wágner, L., Husvéth, F., Bercsényi, M. (2006). Changing of fat content and fatty acid profile of reared pike (Esox lucius) fed two different diets. Aqua Res, 37: 96-101. DOI: 10.1111/j.1365-2109.2005.01402.x

Shimeno, S., Kheyyali, D., Takeda, M. (1990). Metabolic adaptation to prolonged starvation in carp. Nippon Suisan Gakkaishi, 56. 35-41. DOI: 10.2331/suisan.56.35

Pilkis, S.J., Granner, D.K. (1992). Molecular physiology of the regulation of hepatic gluconeogenesis and glycolysis. Ann Rev Physiol. 54. 885-909. DOI: 10.1146/annurev.ph.54.030192.004321

Raclot, T. (2003). Selective mobilization of fatty acids from adipose tissue triacylglycerols. Prog Lipid Res 42. 257-88. DOI: $\underline{10.1016 / S 0163-7827(02) 00066-8}$

Rossi, A., Cazenave, J., Bacchetta, C., Campana, M., Parma, M.J. (2015). Physiological and metabolic adjustments of Hoplosternum littorale (Teleostei, Callichthyidae) during starvation. Ecol Indic 56. 161-170. DOI: 10.1016/j.ecolind.2015.04.001 
Salam, A., Davies, P.M.C. (1994). Body composition of northern pike (Esox lucius L.) in relation to body size and condition factor. Fish Res 19. 193-204. DOI: 10.1016/0165-7836(94)90038-8

SPSS For Windows Version 10, 1999.Copyright SPSS Inc, Chicago IL

Szabó, A., Fébel, H., Mézes, M., Horn, P., Balogh, K., Romvári, R. (2005). Differential utilization of hepatic and myocardial fatty acids during forced molt of laying hens. Poultry Science, 84. 106-112. DOI: $\underline{10.1093 / p s / 84.1 .106}$

Szczepkowski, M. (2009). Impact of selected abiotic and biotic factors on the result of rearing juve-nile stages of Northern pike (Esox lucius L.) in recirculating systems. Archives of Polish Fisher-ies 17. 107-147. DOI: 10.2478/v10086-009-0010-3

Szczepkowski, M., Zakes, Z., Kapusta, A., Sczcepkowska, B., Hopko, M., Jarmolowicz, S., Kowalska, A., Kozlowski, M., Partyka, K., Piotrowska, I., Wunderlich, K. (2012). Growth and survival in earthen ponds of different size juvenile pike reared in recirculating aquaculture systems. Archives of Polish Fisheries, 20, 267-274. DOI: 10.2478/v10086-012-0030-2

Varga. D., Hancz, Cs., Szabó , A. (2020). Selective mobilization of fatty acids in common carp (Cyprinus carpio) during long-term starvation. AACL Bioflux. 13. 1366-1373.

Varga, D., Molnár, T., Romvári, R., Szabó, A. (2014). Preliminary results on the somatic and body compositional changes in juvenile common carp during long term starvation. Acta Agraria Ka-posvarienis. 18: 50-54.

Varga, D., Hancz, Cs., Molnár, T., Szabó, A. (2016). Alterations in serum metabolites and enzymes of juvenile common carp (Cyprinus carpio L.) during longterm starvation. Acta Agraria Kaposvarienis. 20. 36-39.

Wolnicky, J., Gorny, W. (1997). Effects of commercial dry diets and water temperature on growth survival of Northern pike Esox lucius L., larvae. Polish Archives of Hydrobiology 44. 377-383.

Zajic, T., Mraz, J., Sampels, S., Pickova, J. (2013). Fillet quality changes as a result of purging of common carp (Cyprinus carpio L.) with special regard to weight loss and lipid profile. Aquaculture. 400-401. 111-119. DOI: 10.1016/j.aquaculture.2013.03.004

(C) Copyright 2021 by the authors. This is an open access article under the terms

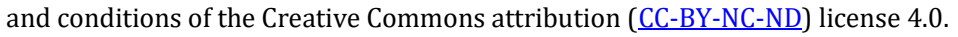

